Review

\title{
Periodontal Wound Healing and Tissue Regeneration: A Narrative Review
}

\author{
Young-Dan Cho, Kyoung-Hwa Kim (D), Yong-Moo Lee, Young Ku and Yang-Jo Seol *(D)
}

Citation: Cho, Y.-D.; Kim, K.-H.; Lee, Y.-M.; Ku, Y.; Seol, Y.-J. Periodontal Wound Healing and Tissue Regeneration: A Narrative Review. Pharmaceuticals 2021, 14, 456. https://doi.org/10.3390/ph14050456

Academic Editors: Yayoi Kawano, Viorica Patrulea, Mitsutoshi Sato, Olivier Jordan and Takehisa Hanawa

Received: 15 April 2021

Accepted: 11 May 2021

Published: 12 May 2021

Publisher's Note: MDPI stays neutral with regard to jurisdictional claims in published maps and institutional affiliations.

Copyright: (c) 2021 by the authors. Licensee MDPI, Basel, Switzerland. This article is an open access article distributed under the terms and conditions of the Creative Commons Attribution (CC BY) license (https:/ / creativecommons.org/licenses/by/ $4.0 /)$.
Department of Periodontology, School of Dentistry and Dental Research Institute, Seoul National University and Seoul National University Dental Hospital, Seoul 03080, Korea; cacodm1@snu.ac.kr (Y.-D.C.); perilab@snu.ac.kr (K.-H.K.); ymlee@snu.ac.kr (Y.-M.L.); guy@snu.ac.kr (Y.K.)

* Correspondence: yjseol@snu.ac.kr; Tel.: +82-2-2072-0308

\begin{abstract}
Periodontal disease is a major public health issue, and various periodontal therapies have been performed to regenerate periodontal tissues. The periodontium is a complex structure composed of specialized tissues that support the teeth, and most periodontal surgeries are invasive procedures, including a resection of the gingiva or the alveolar bone. The periodontal wound healing process is slightly different from cutaneous wound healing and is similar to fetal healing, being almost scar-free. The aim of this review article is to provide an overview of periodontal wound healing and discuss various surgical and pharmaceutical approaches to achieve stable wound healing and improve the treatment outcomes. In addition, detrimental and limiting factors that induce a compromised prognosis are discussed, along with the perspective and future direction for successful periodontal tissue regeneration.
\end{abstract}

Keywords: periodontium; periodontal tissue regeneration; wound healing

\section{Introduction}

The periodontium acts as a supporting apparatus for the teeth and is a complex structure consisting of soft and hard tissues [1]. The main functions of the periodontium are to ensure that the teeth are attached to the bones; to protect the nerves, blood vessels, and teeth from injuries; and to provide a barrier to the underlying structures from the oral microbiome. Soft tissue includes the gingiva, mucosa, and periodontal ligament (PDL), and hard tissue includes the cementum and the alveolar bone (Figure 1).

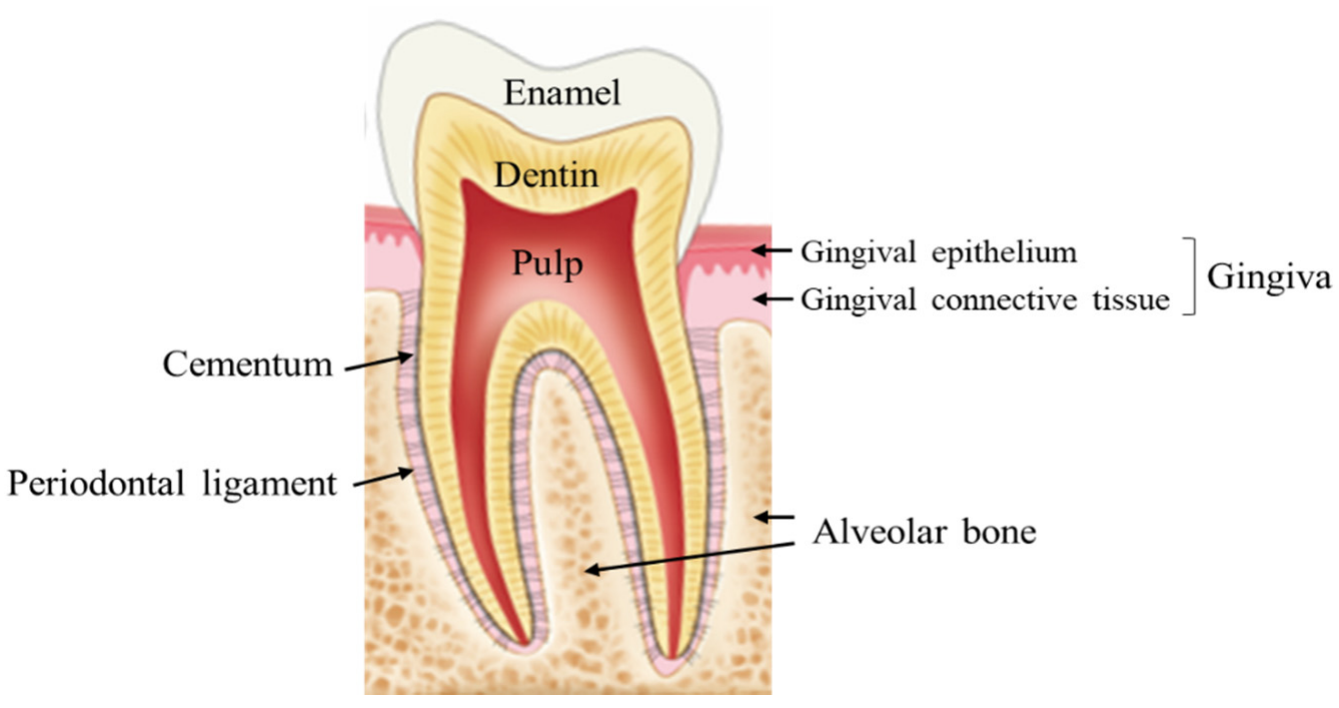

Figure 1. The structure of periodontium. 
The gingiva is a covering tissue that protects the alveolar bone from external stimuli such as microbial attack or mechanical force and consists of epithelial and connective tissues. The general risk factor of periodontal disease is oral microbial infection, which can induce inflammation of the gingiva, and if not treated on time, it affects the periodontium in general $[2,3]$. Periodontal disease is the most common oral disease with a high prevalence of $20-50 \%$ of the world population [4]. Gingivitis and periodontitis are typical periodontal diseases [1]. Gingivitis is the mildest form of periodontal disease, which is limited to gingival inflammation and is reversible [5]. Conversely, periodontitis is irreversible, accompanied by alveolar bone defect, can induce tooth mobility when untreated, and finally, leads to tooth extraction [6]. Periodontal defect is caused by chronic pathological conditions, such as periodontitis, and exhibits the loss of gingiva, periodontal ligament, and alveolar bone. Various procedures to support the regeneration of the periodontal tissue as well as therapeutics to enhance the wound healing process have been studied. A specialized oral environment with saliva and oral microorganisms can affect the defect formation and wound healing process. The objective of this review is to provide an overview of periodontal wound healing and discuss the complications and factors influencing the healing process and therapeutics for improving periodontal wound healing.

\section{Normal Wound Healing}

Wound healing is a dynamic process, which has been a challenge in the clinical setting after treatment. Much effort has been focused on wound management for developing healing techniques and new treatment approaches. Basically, the wound healing process consists of four distinct but overlapping phases [7]: 1. hemostasis and coagulation, 2. inflammation, 3. cell proliferation, and 4. wound remodeling and maturation (Figure 2). This general principle of wound healing also applies to periodontal wound healing [8]. The wound healing procedure involves several types of cells, extracellular matrix, cytokines, and growth factors. Understanding wound healing with regard to various aspects of cells, molecules, physiology, and biochemistry is important to regenerate tissues that are functionally and structurally indistinguishable from the original tissue and not repaired tissue with fibrotic scars. If there is an injury that damages the vessel, hemorrhage is the first process to begin on the wound site. Under normal conditions, a molecular machinery for blood clot formation is immediately operated, protecting the injury site and serving the provisional matrix for cell migration. Blood clot formation continues to the initial inflammatory stage, in which inflammatory cells, including polymorphonuclear neutrophils and monocytes, are activated. These cells clean the wounds of necrotic tissue and bacteria and secrete various enzymes for wound debridement. This inflammatory response shifts into the late phase where macrophages move into the wound area and secrete cytokines or growth factors for the cells involved in the wound healing process. Following the inflammatory stage, granulation tissue formation is initiated with collagen accumulation. Cytokines and growth factors by macrophages induce the migration and proliferation of fibroblasts and endothelial cells into the wound site. This cell-rich granulation tissue activates the phase of matrix formation and maturation. Fibroblasts replace the provisional extracellular matrix by producing a new collagen-rich matrix, and the endothelial cells are involved in angiogenesis for vascularization. Subsequently, wound epithelization is conducted by epithelial cells from the basal layer. The granulation tissue maturation leads to tissue regeneration or repair, which is decided by two main factors: available cells and cell recruiting signals. The skin and gingiva, typical body covering tissues, are considered structurally and functionally homogenous tissues showing similar healing patterns in response to injury. Both are characterized by the presence of keratinized epithelium with underlying connective tissue, which acts as a barrier to microorganisms and other contaminants [9]. 


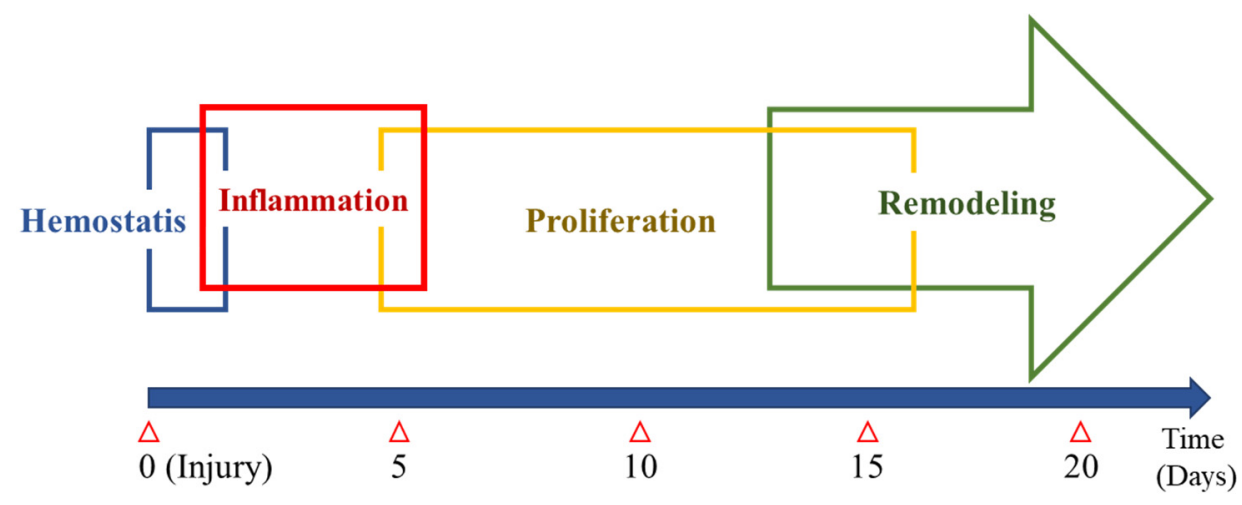

Figure 2. Wound healing process. After injury, wound healing begins with the following process: 1. hemostasis and coagulation, 2. inflammation, 3. cell proliferation, and 4. wound remodeling and maturation.

\section{Distinct Characteristics of the Oral Wound}

The cutaneous and gingival tissues follow similar macroscopic healing patternshemostasis, inflammation, proliferation, and remodeling of the collagen-but are accompanied by microscopic changes at the molecular level and show a distinguished healing response. In the oral cavity, wound healing occurs in warm mouth fluids containing millions of oral microorganisms that might be perceived as detrimental to the healing process [10]. Nevertheless, wounds in the oral cavity heal much faster compared to skin wounds, with rapid re-epithelialization and re-modeling resulting in minimal scar formation [11]. This advantage could be explained by the presence of growth factors or cytokines in the saliva and the important role of fibroblasts. Saliva contains a number of important molecules, such as epidermal growth factors, lysosomes, and lactoferrin, which have antimicrobial and anti-inflammatory properties [12]. Fibroblasts are the main cells of gingival tissue and play an important role in wound healing, especially extracellular matrix (ECM) remodeling by the synthesis of ECM components (such as collagen, fibronectin, hyaluronan, and elastin) and the secretion of matrix metalloproteinase and tissue inhibitor of metalloproteinase [13]. The only exception in the healing potential is excisional wounds on the hard palate. The connective tissue is very thin at palate; therefore, the depth of the wound can reach to the surface of cranial bone and the healing is slow [14]. Recent research has revealed the molecular differences between oral and skin wound healing. Most studies have suggested that an oral wound is in the "primed" state for wound healing compared to a skin wound (Table 1) [9,15-17].

\subsection{Attenuated Inflammatory Reaction}

Regarding the phenomenon of scarless and rapid healing, some studies have tried to explain it using the similarity of oral and fetal wounds that includes decreased levels of pro-inflammatory cytokines, such as IL-6 and IL-8 [11], and inflammatory cells, including macrophages and neutrophils [18], but the healing process is not identical. Compared to adult skin wounds, fetal wounds showed decreased levels of transforming growth factor- $\beta 1$ and increased IL-10; however, no change was seen in oral wounds. Additionally, other studies have suggested positive effects on the inflammation of saliva containing growth factors, protease inhibitors, and cytokines [19]; however, a clear explanation is still not characterized with controversial results [20]. Further in-depth research about the critical difference of oral wounds could provide good candidate biomarkers for wound healing acceleration materials. 
Table 1. Characteristics and differences of oral and skin wounds.

\begin{tabular}{|c|c|c|}
\hline & Oral Wound & Skin Wound \\
\hline Re-epithelialization & \multicolumn{2}{|c|}{$\begin{array}{l}\text { Re-epithelialization in oral wound is faster than } \\
\text { skin wound }\end{array}$} \\
\hline Re-epithelialization (24 h) & $100 \%$ & $40 \%$ \\
\hline Inflammation & \multicolumn{2}{|c|}{$\begin{array}{l}\text { Inflammatory reaction is reduced and resolution is faster } \\
\text { in oral wound than skin }\end{array}$} \\
\hline $\begin{array}{l}\text { Inflammatory cells (Neutrophils, } \\
\text { T cells, Macrophages) }\end{array}$ & $\downarrow$ & $\uparrow$ \\
\hline Cytokines (IL-1 $\beta$, IL-6, IL- $\alpha$, TNF- $\alpha$ ) & $\downarrow$ & $\uparrow$ \\
\hline Angiogenesis & \multicolumn{2}{|c|}{ Angiogenic response is decreased in oral wound } \\
\hline Vessel density & $\downarrow$ & $\uparrow$ \\
\hline VEGF & $\downarrow$ & $\uparrow$ \\
\hline ECM & \multicolumn{2}{|c|}{ MMT/TIMP ratio is decreased in oral wound } \\
\hline Matrix metalloproteinases (MMP) & $\downarrow$ & $\uparrow$ \\
\hline $\begin{array}{l}\text { Tissue inhibitor of } \\
\text { metalloproteinase (TIMP) }\end{array}$ & $\uparrow$ & $\uparrow$ \\
\hline SCAR & \multicolumn{2}{|c|}{ Reduced scar formation is observed in oral wound } \\
\hline TGF- $\beta 1 / \beta 3$ & $\downarrow$ & $\uparrow$ \\
\hline
\end{tabular}

\subsection{Differential Angiogenesis Pattern}

Compared to skin wounds, oral wounds exhibit reduced levels of vascular endothelial growth factor expression and more muted angiogenic response, which was supported by dissimilar levels of hypoxia and hypoxia inducible factor-1alpha (HIF-1 $\alpha)$ expression. Skin wounds have been shown to be significantly more hypoxic and to have higher levels of HIF- $1 \alpha$ than oral wounds [21]. However, this finding of decreased angiogenesis could be open to controversy, since unwounded oral mucosa is more vascularized than the skin [18].

\section{Periodontal Treatment and Wound Healing}

In periodontal surgery, the wound healing pattern is largely divided into two types: primary and secondary healing [22]. Primary healing is a proper procedure for wound healing, which is performed when the gingival tissue is perfectly replaced or closely approximated in the same position pre- and post-operatively. The healing pattern shows rapid healing time with little or no scarring and low infection risk. Conversely, secondary healing occurs when the wound site is not covered by epithelial tissue due to accidents (rupture of suturing and loss of covering materials, etc.) or intention (apically positioned flap and tooth extraction socket, etc.).

\subsection{Tooth Extraction}

Tooth extraction is one of the most common surgical procedures performed in dental clinics. When diagnosed with hopeless tooth condition due to periodontitis, dental caries, trauma, etc., tooth extraction is performed. The subsequent process of socket healing has become an important subject of research and clinical practice for the successful healing and restoration in the missing region with dental implants. The socket healing pattern post tooth extraction follows a bone healing process with a series of orderly biological events. In general, after that tooth is isolated from the socket in the alveolar bone, the socket is filled with blood clots. Re-epithelization is progressed around $24 \mathrm{~h}$ after extraction, and then blood clots are replaced by granulation tissue. The extraction socket is gradually filled with bone, and the bone remodeling process proceeds around 6 months after extraction (Figure 3). The process of socket healing has been widely studied in human and animal models, such as canines, rats, and mice, with radiographical and histological methods. 
Although the sequence of biological events was similar, a difference was seen in healing time [23]. The socket healing process is accompanied by the loss of alveolar bone height and width due to bone remodeling, including bone formation and resorption. The degree of bone resorption during the remodeling procedure depends on various factors, including local factors such as the quality and quantity of alveolar bone, the presence of inflammation, the use of grafting materials, and oral hygiene, and systemic factors such as smoking, nutrition, and medical condition. A fresh extraction socket, such as extraction due to dental caries or tooth fracture, mostly follows a favorable healing procedure; however, a periodontally compromised socket with severe bone defect by chronic pathologic lesion can result in erratic healing by connective tissue infiltration instead of bone formation [24].
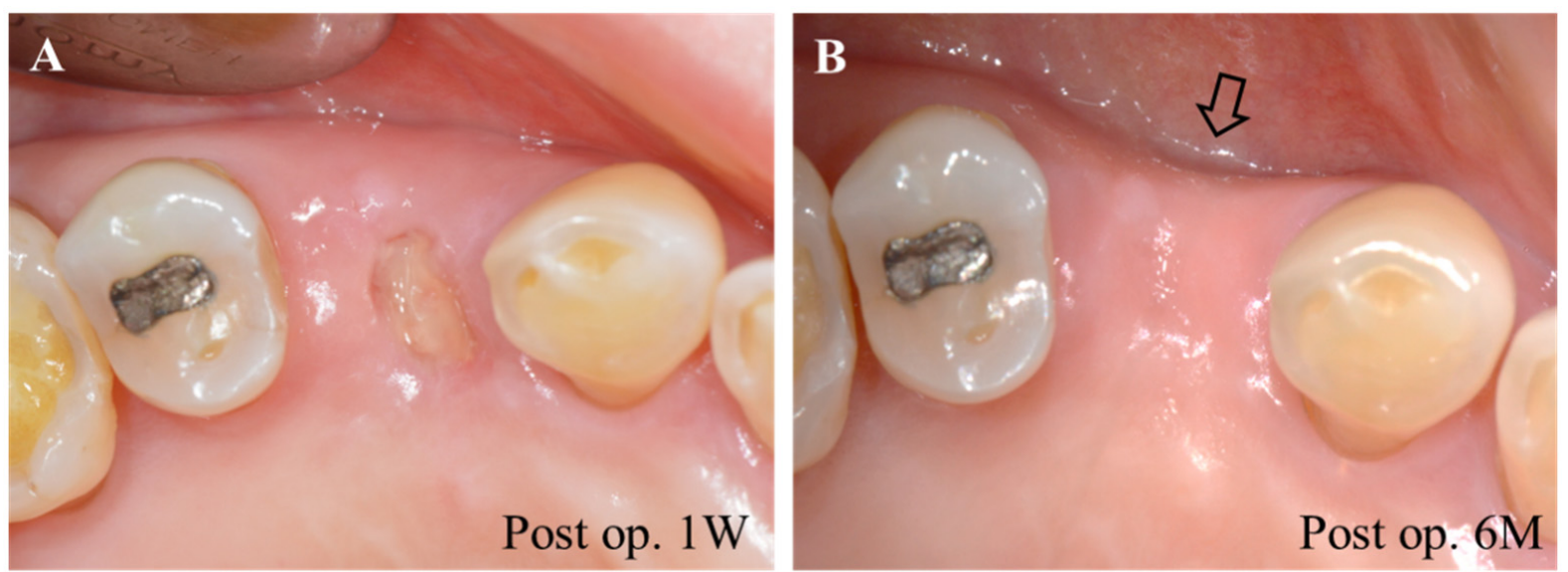

Figure 3. Extraction socket healing. (A) Re-epithelization is in progress at post op. 1 week. (B) Alveolar bone loss is observed after 6 months of socket healing; the convex alveolar bone has become concave (arrow).

\subsection{Resective Periodontal Surgery}

In the treatment of patients with periodontitis, surgical intervention (such as scaling and root planing) could be required after completion of the non-surgical phase. A periodontal flap is a section of gingiva or mucosa which is surgically separated from the underlying tissues such as the alveolar bone and connective tissue. The periodontal flap operation enables access to root surfaces for cleaning and to remove inflamed soft or hard tissue to reestablish a stable periodontal structure. Depending on the bone exposure after flap reflection, the periodontal flaps are classified as partial-thickness or full-thickness flaps. For favorable healing, the entire surgical procedure should be planned in detail with regard to type of incision, flap design, flap closure, suture, etc., before the procedure. The flap design with a sharp and correct incision is important to preserve good blood supply for the maintenance of vascularization and a reduction in postoperative shrinkage, and an exact flap position with stable suturing is crucial for the stability of the blood clot in the wound site. To improve the healing potential, minimally invasive surgery (MIS), a surgical technique to minimize flap reflection, has been introduced to reduce the wound size and healing time with decreased pain and infection risk. MIS is defined as "refinements in existing basic surgical techniques that are made possible by the use of surgical microscopes and subsequent improved visual acuity," and three principles are required to be fulfilled [25]: 1 . enhancing the surgical ability by the improvement of motor skills, 2 . exact primary apposition of the wound edge by passive wound closure, and 3. the application of micro surgical instruments and sutures to reduce tissue trauma. Based on this concept, in 2007, Cortellini and Tonetti suggested the minimally invasive surgical technique (MIST) in periodontal surgery [26], and the use of a microscope and microsurgical instrument was necessary to increase the surgical prognosis. Several studies have shown the advantages of MIST, which include rapid wound healing with less granulation or scar tissue formation and less inflammation or pain. 


\subsection{Regenerative Periodontal Surgery}

The treatment of periodontal disease has been gradually shifting from resective to regenerative therapy with progress in the understanding of periodontal wound healing. The development of biomaterials, instruments, and techniques has supported the paradigm shift focusing on actual periodontal tissue regeneration, including functional PDL formation [27]. Periodontal tissue regeneration is largely classified into guided tissue regeneration (GTR) and guided bone regeneration (GBR). Simply, GTR refers to the regeneration of periodontal attachment including bone, PDL, and cementum, whereas GBR refers to works on the edentulous area, such as bone grafting and ridge augmentation. GTR is a representative procedure of regenerative surgery in the periodontally compromised site and is defined as follows: "procedures attempting to regenerate lost periodontal structures through differential tissue response" [28] (Figure 4). In periodontitis, alveolar bone resorption is accompanied with gingival inflammation, which causes the breakdown of periodontal attachment. Theoretically, periodontal defects (including soft tissue and hard tissue) cannot be regenerated to the original structure by repair. For successful regeneration, cells that have the ability to form cementum, PDL, and bone should move to the defect site and activate the differentiation potential from progenitor cells. However, practically, epithelial cells move rapidly to the defect site and inhibit the proliferation and differentiation of progenitor cells for the maturation of cementum, PDL, and bone; eventually, the repair would be superior to the regeneration. Therefore, the concept of "guide" using a barrier was introduced for selective cell repopulation, proliferation, and differentiation. As a barrier, resorbable or non-resorbable membranes have been widely used to prevent gingival epithelium or connective tissue entering the bony defect site and to induce osteogenesis and PDL regeneration. The membrane creates a space acting as a scaffold for vascularization and cell ingrowth from the base of the periodontal defect, prevents bacterial invasion, and isolates the inner space from undesirable cells after therapy. Furthermore, it provides a good environment for favorable wound healing, acting as a double layered gingival flap to improve the stability of the blood clot and protect the interface between the root surface and healing tissues, preventing the rupture of the surgical wound site.
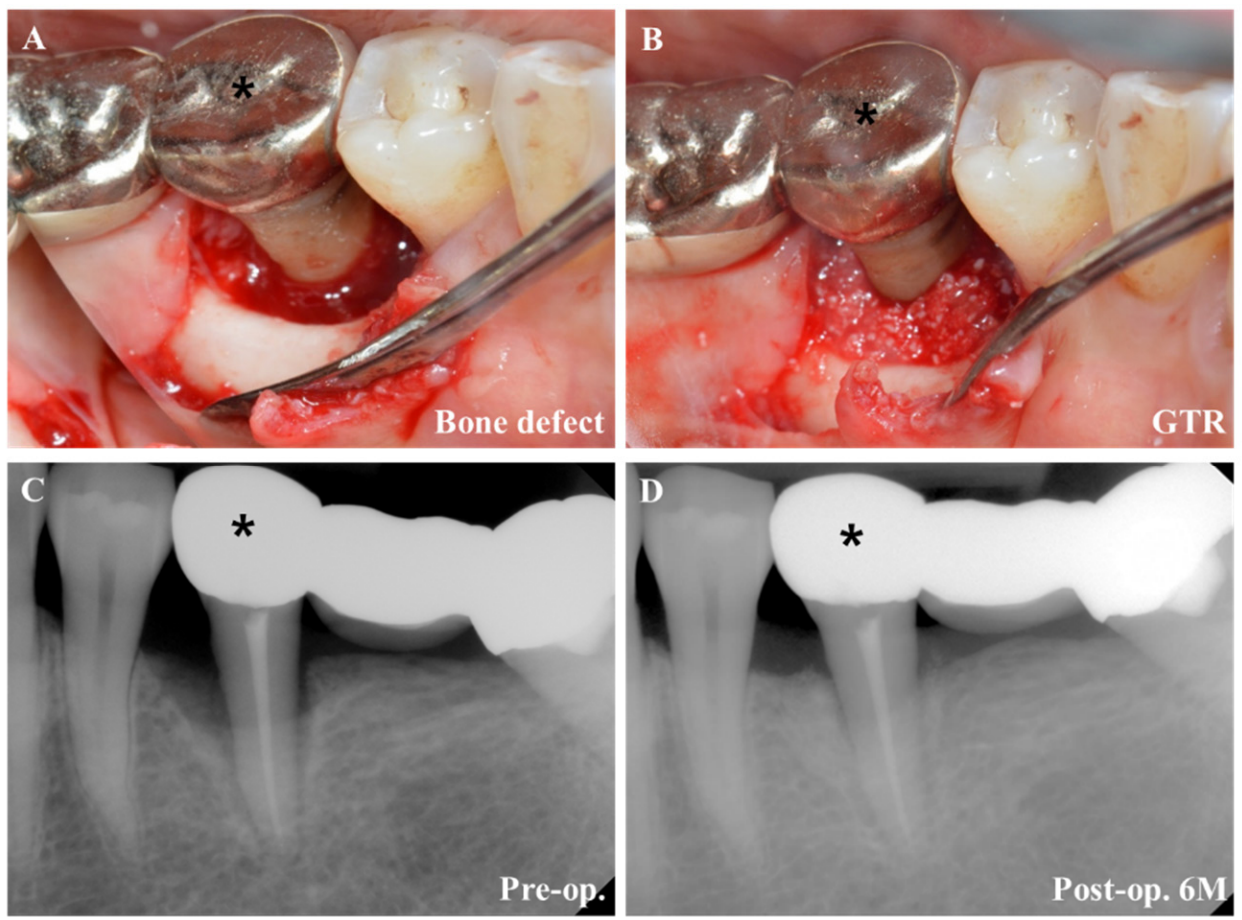

Figure 4. GTR. (A) Severe alveolar bone defect around tooth $\left(^{*}\right)$ is observed. (B) After cleaning the defect, bone grafting was performed. (C) Preoperative condition observed in radiograph. (D) Postoperative periodontal tissue regeneration was observed in radiograph. 


\section{Complications after Periodontal Treatment}

A complication is a secondary disorder arising as a consequence of the primary disease or condition. The complications arising after periodontal therapy include postoperative infection, bleeding, swelling, pain, bruising, and adverse tissue changes. Among them, the first three can interfere with the wound healing procedure and alter the treatment outcomes [29].

\subsection{Postoperative Infection}

Due to the distinct character of the oral cavity —an open space toward the outside—and food intake, infection could be a risk factor inhibiting the normal wound healing process. Oral microbiome on the wound bed is one of the most critical barriers for the infection. The wound healing process could be impaired by pathological microorganisms that produce free-radicals, destructive enzymes, and toxins and down-regulate the immune response and inhibit collagen formation. Generally, the occurrence of bacteremia depends on the degree of trauma during treatment and could be prevented by prophylactic antibiotics. Amoxicillin is widely used as the first choice for infection prophylaxis [22].

\subsection{Bleeding}

Postoperative bleeding is always followed at varying degrees. Within $12 \mathrm{~h}$ of surgery, some bleeding is considered normal; however, persistent hemorrhage or oozing could be problematic to wound healing [30]. Postoperative bleeding is classified into primary, reactionary, and secondary hemorrhage. Primary hemorrhage occurs at the time of operation, reactionary hemorrhage occurs 2-3 h after operation due to the loss of vasoconstrictor effect under anesthesia, and secondary hemorrhage occurs up to 2 weeks after the operation due to infection. In uncontrolled hemorrhage, various methods are applied for bleeding control. The hemostatic agents typically used are silver nitrate and ferric sulphate, and materials include oxidized cellulose, suturing, and collagen or gelatin sponges. Furthermore, bone wax is used to prevent bleeding from bones, and electric devices used to seal the damaged vessel are effective in the control of extensive bleeding. Hemostasis in patients with a bleeding disorder or taking anticoagulants should be handled with great caution. Preoperative cessation of anticoagulants and the preparation of blood transfusion in case of emergency are considered.

\subsection{Swelling}

Swelling is defined as the enlargement of a body part as a result of inflammation or filling with tissue fluids and is considered to be a normal postoperative reaction until it interferes with wound healing [31]. This expected swelling is generally related to surgical range and operating time, and especially associated with increased blood supply to the surgical site. If swelling persists, the wound site can reopen despite the suture, and primary healing will not be possible. The administration of antibiotics and steroids is recommended pre- or post-operatively to prevent unexpected swelling from disturbing the process of healing [32].

\subsection{Scar Formation}

Scar formation, known as fibrosis, is an inevitable result of cutaneous wound healing; however, it varies widely depending on the anatomical sites. Scar formation occurs when normal physiological process is not achieved. Most oral wounds do not cause serious scars; however, fibrosis can occur when healthy bone does not support the base of the wound, such as in congenital defects, lip clefts, and/or palate clefts [33]. Additionally, a persistent inflammation in the chronic wound can result in delayed healing and fibrosis [16].

\section{Factors Affecting Periodontal Wound Healing}

It is important to recognize risk factors related to the wound healing process to achieve favorable wound healing after treatment. 


\subsection{Vascularization, Flap Design, and Incision}

In periodontal surgery, a comprehensive anatomical understanding is significant for flap design with incision. To prevent complications in wound healing and angiogenesis, an accurate cognition on the branching of periosteal vessels is required [34,35]. It is widely accepted that flap elevations without a vertical incision benefit from accelerating blood supply and favorable wound healing, resulting in the improvement of esthetic outcomes, better patient satisfaction, and minimal risk of scarring [34,36]. In particular, scarring on the anterior part by impaired blood supply creates an esthetic problem. Vertical incision, such as a coronally advanced flap in vertical bone augmentation, is unavoidable, and the incision should be placed at the mesial side of the flap to avoid the interruption of vascular flow from the posterior end to the anterior end of the scar [37]. Additionally, long time periodontal surgery with a vertical incision and additional local anesthetics such as epinephrine can induce ischemia in the mucogingival flap $[38,39]$.

\subsection{Aging (Senescence)}

Aging is a biological process characterized by a decrease in cellular function that is induced by a gradual deficiency in regenerative reactions with a dramatic change in gene expressions in body tissues [40]. After tissue injury, various types of cells (neutrophils, lymphocytes, monocytes, fibroblasts, endothelial cells, and keratinocytes) are recruited, which secrete and organize the components of the ECM, including collagen, proteoglycan, and fibronectin. Normal periodontal wound healing requires normal reactive cells and a healthy ECM; however, aging affects both cell response and physiology of the ECM unfavorably [41]. Differences in the wound healing process by aging are as follows. In the inflammatory phase of wound healing, aging may prolong the production of inflammatory cytokines, which delay wound healing and tissue fibrosis, reducing the regenerative potential. Senescence-associated secretory phenotype (SASP) is characterized by a proinflammatory trait of senescent cells, with the involvement of CCAAT/enhancer and nuclear factor-kB (NF-kB) associated with the secretion of chemokines, cytokines, and proteolytic enzymes. Following the altered inflammatory phase, new tissue formation and remodeling phases are also affected. Aging decreases collagen synthesis, cell migration, proliferation, and differentiation in the new tissue formation phase and increases the production and activity of matrix metalloproteinases (MMP) and apoptosis in the tissue remodeling phase [42].

\subsection{Diabetes Mellitus (DM)}

DM is a representative disease exhibiting an impairment in wound healing [43]. This impaired healing process in DM patients involves complex pathophysiological mechanisms. Hypoxia, which is induced by insufficient perfusion or angiogenesis, is a critical risk factor in DM that amplifies early inflammatory responses, thus increasing the production of oxygen radicals [44]. Hyperglycemic conditions aggravate wound healing with hypoxia by increasing the oxidative stress and formation of advanced glycation end-products [45]. High levels of MMP and the dysfunction of fibroblasts and keratinocytes inhibit the normal repair process, resulting in tissue destruction. Dysregulated immune-related cell functions, including defects in bactericidal capacity, leukocyte chemotaxis, phagocytosis, and dysfunctions of fibroblasts, also add to impaired repair. Additionally, neuropathy in DM may contribute to impaired wound healing with a decrease in neuropeptides, including substance $\mathrm{P}$, calcitonin related peptide, and nerve growth factor [46].

\subsection{Smoking}

The negative effects of smoking on wound healing are well known [47]. In periodontal surgeries, including dental implant placement, impaired healing in smokers has been reported [48-51]. Nicotine, a major component of tobacco, is quickly absorbed by diffusion through the buccal mucosa and produces a variety of systemic effects $[52,53]$. Reportedly, nicotine inhibited the fibroblast activities of fibronectin and collagen synthesis, 
and increased collagenase activity, inducing collagen degradation [52,54]. In periodontal disease, gingival bleeding is lesser in smokers than in non-smokers because of decreased gingival blood flow due to nicotine's vasoconstrictive effect. This effect leads to insufficient vascularization of the gingiva, in turn lowering the wound healing potential and increasing the chance of bacterial infection [55]. Additionally, Imamura et al. reported that nicotine reduced epithelial cell migration, which is important for re-epithelialization during wound healing, through MAPL ERK1/2 and p38 signaling pathways [56]. Based on this evidence, smoking delays wound healing and adds various complications, such as wound rupture, infection, tissue necrosis, and epidermolysis [57].

\section{Therapeutics for Periodontal Wound Healing}

\subsection{Biopharmaceutical Approaches}

\subsubsection{Enamel Matrix Derivative (EMD)}

EMD was introduced as a tissue healing agent derived from proteins during cementogenesis in the tooth development to stimulate tissue regeneration. Amelogenin is the main protein component of EMD, and EMD has been focused in GTR in particular because it promotes PDL fibroblast proliferation and inhibits epithelial growth, which is a key and necessary mechanism in GTR. Emdogain ${ }^{\circledR}$ (Straumann, Switzerland) is a commercial product containing a mixture of EMDs that promote periodontal tissue regeneration in the application at the root surface and have osteopromotive properties [58,59]. Furthermore, Emdogain ${ }^{\circledR}$ enhances wound healing in the gingival tissue with reduced complications, such as inflammatory reaction and pain, even in skin wound healing [60,61]. In vitro and in vivo studies have shown that EMD reduces the secretion of chemokines and proinflammatory cytokines related to chemotaxis, angiogenesis, inflammation, and fibroplasia, and its effect is critical in early wound healing according to a clinical study [61]. Diabetes is one of the main risk factors for wound healing, and Takeda et al. reported that EMD promotes periodontal tissue regeneration through the Akt/VEGF signaling pathway even in diabetic patients [62].

\subsubsection{Collagen}

Collagen is a naturally available, as well as the most abundant, protein present in the extracellular matrix and acts as an important component of physical and functional structure in the body [63]. With its chemotactic character, collagen improves the fibroblasts' migration, proliferation, and differentiation of specialized cells. Additionally, collagen plays an important role in wound healing, including platelet activation and angiogenesis [64]. In addition to these advantages, collagen has been widely used in various formulations in periodontal surgery due to its easy manipulation. However, its hydrophilic properties can act as a disadvantage, leading to rapid enzymatic degradation and swelling. Collagen membrane is used as a barrier to prevent the preoccupancy of epithelial cells in the periodontal defect site in GTR (Table 2). Various types of membranes used in GTR derived from different animals (porcine, bovine, and equine) consist of type I or III collagen or both. Collagen is also applied to the tooth extraction socket for bleeding control and blood clot stabilization. This hemostatic collagen is highly absorbent; therefore, it absorbs the blood as soon as it is applied to the bleeding site, serving as a mechanical obstruction. Furthermore, when collagen comes in contact with blood, it causes platelet aggregation, releasing thromboxane $\mathrm{A} 2$, and creates an artificial clot-like structure. 
Table 2. Clinical application of collagen in periodontal treatment.

\begin{tabular}{|c|c|c|c|}
\hline Types & Application & Commercial Product (Manufacturer) & Reference \\
\hline \multirow{4}{*}{ Sponge } & \multirow{4}{*}{$\begin{array}{ll}- & \text { Hemostasis } \\
- & \text { Reduction in pain } \\
- & \text { Soft tissue contouring } \\
- & \text { Wound dressing } \\
- & \text { Socket grafting }\end{array}$} & CollaPlug (Integra LifeSciences Corp.) & {$[65,66]$} \\
\hline & & OraPlug (Salvin) & [67] \\
\hline & & Teruplug (Olympus Terumo Biomaterials) & [68-70] \\
\hline & & Avitene Ultrafoam Collagen Sponge (Davol, Inc.) & {$[71,72]$} \\
\hline \multirow{5}{*}{ Membrane } & \multirow{5}{*}{ - $\quad$ Barrier in GTR or GBR } & Bio-Gide (Geistlich) & [73-78] \\
\hline & & BioMend/OsseoGuard (Zimmer Biomet Inc.) & {$[73,78,79]$} \\
\hline & & Ossix (Datum Dental Ltd.) & {$[80,81]$} \\
\hline & & Periogen (Collagen Corporation) & {$[73,82]$} \\
\hline & & CollaCote/CollaTape (Integra LifeSciences Corp.) & [83-85] \\
\hline
\end{tabular}

\subsubsection{Blood-Derived Products}

Blood-derived products, including platelet rich plasma (PRP), plasma rich growth factor (PRGF), and fibrin sealant, have been used in regenerative surgical procedures. The preparation method is based on concentrating platelets, leukocytes, and growth factors, but their contents are slightly different. PRP consists of platelets and leukocytes, but PRGF does not have leukocytes. Fibrin sealant is derived from blood plasma, which is cryoprecipitated to obtain fibrinogen.

\section{PRP}

PRP is an autologous bioactive substance that has various applications in the medical and dental field, including plastic surgery and periodontal or maxillofacial surgery for the enhancement of wound healing. PRP is obtained from the middle layer of white blood cells and platelets in centrifugated blood. Platelets contain biologically active proteins that bind to the fibrin mesh or ECM and recruit stem cells that promote wound healing [86]. In periodontal treatment, PRP is easily applied to soft or hard tissue therapy. In hard tissue application, PRP enhances the healing of intrabony defects when combined with bone grafting [87]. In soft tissue application, several clinical reports suggested the advantages of PRP, such as accelerated wound healing and improved esthetics [88]. However, the efficacy of PRP in periodontal treatment has been controversial due to diverse or adverse clinical outcomes. PRP may not provide additional effects compared to GBR in relation to dental implants, and the evidence of effects of PRP in sinus elevation seem weak [89]. This may be due to different platelet numbers or PRP concentration related to growth factors [90]. PRP has been somewhat advantageous when used for periodontal tissue regeneration; however, enough controlled clinical trials have not been conducted to prove its efficacy.

\section{PRGF}

PRGF is a second-generation blood-related product, similar to PRP, and requires less venous blood, making it convenient, time-consuming, safe, easy-to-use, and fast healing [91]. In contrast to PRP, PRGF does not contain white blood cells and associated inflammatory byproducts for avoiding the proinflammatory effects of proteases and acid hydrolases [92]. Plasma-derived adhesive molecules, such as fibronectin, fibrinogen, and vitronectin, serve as a matrix for attracting progenitor cells, and platelet concentrates act as reservoirs for growth factors, such as platelet derived growth factor (PDGF), insulin-like growth factor (IGF), transforming growth factor (TGF), and vascular endothelial growth factor (VEGF). PRGF induces fibroblast proliferation and epithelial tissue healing. Due to its gel-like consistency, it seems more ideal for non-surgical application than surgical. In randomized clinical trials, the clinical efficacy of PRGF as an adjunct to non-surgical periodontal treatment has been proved with a reduction in pocket depth and gain in clinical attachment level [91]. Even in surgical procedures, the use of liquid PRGF accelerates bone 
healing in the extraction socket and sinus lift and promotes the osseointegration of dental implants [88].

\section{Fibrin Sealant}

The proteins fibrin and fibronectin play a crucial role in hemostasis and wound healing. If an injury occurs, fibrinogen is activated by thrombin to form insoluble fibrin clots for hemostasis. Wound healing is processed via interactions of cell surface receptors with fibrin and other proteins, including fibronectin. Fibronectin is an adhesive glycoprotein with multiple binding sites for surface receptors on various cells, such as fibroblasts [93]. Fibrin sealant, known as glue, has been used in surgeries for hemostasis and anchoring the graft. The application of fibrin sealant in periodontal surgery also showed excellent hemostatic and tissue adhesive effects [94]. The product of fibrin sealant is composed of thrombin and fibrinogen. When they are mixed together, fibrin clot formation is conducted by the induction of the final stage of the blood clotting pathway. Fibrin sealant enhances mechanical strength and blood clot stability and can be prepared from autologous blood without an immune reaction.

\subsection{Periodontal Dressing Materials}

Periodontal dressing has been introduced for the protection of wounds by preventing post-operative hemorrhage, irritation, and microbial contamination in the surgical site. The first use of a periodontal dressing with iodoform gauze was reported, and then the first commercial product, "Wonderpak," which consists of zinc oxide, eugenol, pine oil, alcohol, and asbestos fibers, was introduced. The two types of periodontal dressings are largely classified according to the gradients: 1 . zinc oxide eugenol (hard type) and 2. zinc oxide non-eugenol (soft type). Zinc oxide non-eugenol dressings are more commonly used because zinc oxide eugenol has disadvantages such as hardness, difficulty of adaptation, burning sensation, or allergic reaction from unreacted eugenol. A widely used non-eugenol dressing is Coe-Pak (Dentsply, Germany), which consists of two types of pastes-base and accelerator (Figure 5). In addition, dressings without zinc oxide or eugenol, such as light curing or collagen-containing periodontal dressings, are also available. Due to its transparent property, a light curing dressing is applied to the anterior part. Collagencontaining dressing promotes wound healing by deposition of the fibers in the granulation tissue. In the past, despite the advantages of periodontal dressing, whether to use or not use it was debatable. The type of dressing used for a wound seems subjective. Presently, it might be accepted that if adequate primary closure of the gingival flap is achieved, there is little necessity to use dressing, but the protection of the surgical area with dressing is recommended when secondary healing is anticipated.
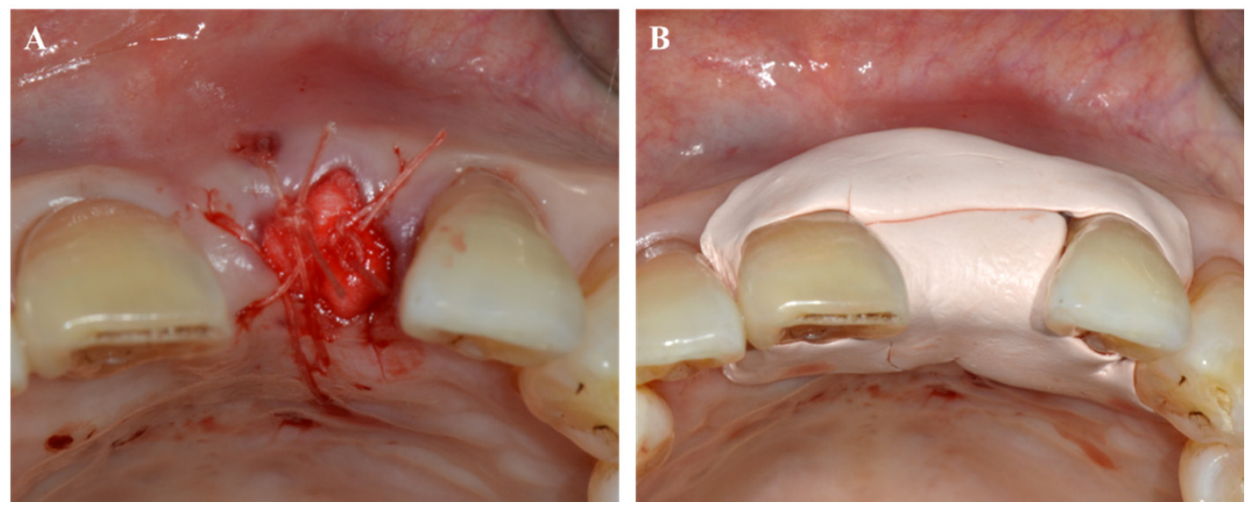

Figure 5. Periodontal dressing application. (A) After tooth extraction, collagen material was applied to the extraction socket. (B) Coe-Pak was applied to the surgical site to protect the wound. 


\subsection{Devices to Improve Wound Healing \\ 7.3.1. Light Amplification by Stimulated Emission of Radiation (Laser)}

The laser has three key elements: power (thermal property), wavelength (optical property), and pulse or wave (operating mode). Two types of lasers are available depending on tissue penetration depth. High-intensity laser therapy (HILT), such as neodymiumdoped yttrium-aluminum-garnet (Nd:YAG), carbon dioxide $\left(\mathrm{CO}_{2}\right)$, erbium, and diodes, is used in the surgical process of not only ablation, vaporization, and coagulation but also the stimulation of wound healing. Conversely, low-level lasers and light-emitting diodes (LEDs) are used as "biostimulators" with lower power than that of surgical lasers. Photobiomodulation therapy (PBMT) is defined as light therapy using low-level lasers and LEDs that promote wound healing by inducing epithelial cell proliferation, antiinflammatory response, pain relief, and inhibition of scar formation [95]. In dentistry, lasers have been widely used in periodontal treatment (Table 3). The best advantage of HILT is hemostasis with easy ablation of the soft tissue. Compared to blade incision, HILT can easily cut and reshape the gingival tissue with reduced pain, bleeding, and suturing [96]. In addition, PBMT is a unique aspect of lasers, which promotes wound healing and reduces inflammation and pain [97,98]. The U.S. Food and Drug Administration (FDA) defined the therapeutic lasers with wavelengths of less than $500 \mathrm{~mW}$ as harmless, classified them as "low-risk devices," and proposed the guideline for laser application in dentistry; the coagulation of extraction sites using diode lasers and $\mathrm{CO}_{2}$ lasers. The advantage of therapeutic lasers is that they stimulate natural biological processes and mainly affect cells with oxidation-reduction (redox) reactions. Healthy cells do not respond strongly to lasers because they cannot increase their redox ability immediately, while damaged cells with low redox level will be quickly stimulated. Light photons absorbed by the mitochondria of the cells increase the amount of adenosine triphosphate, a cellular energy, via the removal of nitric oxide on cytochrome c oxidase and generate reactive oxygen species, which eventually stimulates cell signaling and gene expression-related wound healing.

Table 3. Dental application of therapeutic laser.

\begin{tabular}{|c|c|c|c|c|}
\hline Application & Type & Method & Effect & Ref. \\
\hline Extraction socket & $\begin{array}{l}\text { Combined HILT } \\
\text { and PBMT }\end{array}$ & $\begin{array}{l}\text { HILT ( } 27 \mathrm{~J}) \text { was performed } \\
\text { immediately after tooth } \\
\text { extraction to enhance blood } \\
\text { coagulation, followed by PBMT } \\
(0.7 \mathrm{~J}) 1 \text { day later to } \\
\text { enhance healing }\end{array}$ & $\begin{array}{l}\text { Combined HILT and PBMT } \\
\text { following tooth extraction } \\
\text { hastened wound healing and } \\
\text { preserved alveolar crest } \\
\text { height, suggesting a role in } \\
\text { socket preservation }\end{array}$ & [99] \\
\hline $\begin{array}{l}\text { Recurrent aphthous } \\
\text { stomatitis (RAS) }\end{array}$ & $\begin{array}{l}\mathrm{CO} 2 \text { laser, Nd:YAG laser } \\
\text { and diode laser }\end{array}$ & $\begin{array}{l}\text { Laser treatment included } \\
\text { Nd:YAG laser ablation, CO2 } \\
\text { laser applied through a } \\
\text { transparent gel (non-ablative) } \\
\text { and diode laser in a low-level } \\
\text { laser treatment (LLLT) mode }\end{array}$ & $\begin{array}{l}\text { The use of lasers (CO2 laser, } \\
\text { Nd:YAG laser and diode laser) } \\
\text { to relieve symptoms and } \\
\text { promote healing of RAS }\end{array}$ & [100] \\
\hline $\begin{array}{l}\text { Inflammatory fibrous } \\
\text { hyperplasia }\end{array}$ & $\begin{array}{l}\text { Diode laser } \\
\text { systems }\end{array}$ & $\begin{array}{l}\text { Randomized, split-mouth } \\
\text { clinical trial; comparative } \\
\text { evaluation of diode laser and } \\
\text { scalpel surgery }\end{array}$ & $\begin{array}{l}\text { Bleeding and bacterial count } \\
\text { was low in the laser group }\end{array}$ & [101] \\
\hline Frenectomy & Nd:YAG laser treatment & $\begin{array}{l}\text { Randomized clinical trial on } \\
\text { postoperative discomfort } \\
\text { after Nd:YAG laser and } \\
\text { conventional frenectomy }\end{array}$ & $\begin{array}{l}\text { Nd:YAG laser treatment used } \\
\text { for frenectomies provides } \\
\text { better postoperative comfort } \\
\text { (pain, chewing, talking) }\end{array}$ & [102] \\
\hline $\begin{array}{l}\text { Harvesting de-epithelialized } \\
\text { palatal graft }\end{array}$ & $\begin{array}{l}\text { Diode laser } \\
\text { systems }\end{array}$ & $\begin{array}{l}\text { Randomized clinical trial: } \\
\text { comparative evaluation of diode } \\
\text { laser and scalpel surgery }\end{array}$ & $\begin{array}{l}\text { Laser technique decreased } \\
\text { post-operative morbidity }\end{array}$ & [103] \\
\hline Free gingival graft & PBMT & $\begin{array}{l}\text { A split-mouth triple-blind } \\
\text { randomized controlled } \\
\text { clinical trial }\end{array}$ & $\begin{array}{l}\text { PBMT accelerated the rate } \\
\text { of epithelialization at the } \\
\text { donor site }\end{array}$ & [104] \\
\hline
\end{tabular}




\subsubsection{Hyperbaric Oxygen}

Hypoxia is a microenvironmental feature of inflammatory disease, wound healing, and cancers, in which the demand of $\mathrm{O}_{2}$ is higher [105]. Hypoxia and low $\mathrm{O}_{2}$ pressure have a negative effect on the function of inflammatory cells and fibroblasts during the healing procedure [106]. Hyperbaric oxygen therapy (HBOT) is used for therapeutic purposes with $100 \% \mathrm{O}_{2}$ under a certain pressure. HBOT increases the oxygen tension in the arterial blood and sequentially improves the cellular oxygen tension, which stimulates angiogenesis and wound healing, and has bactericidal or bacteriostatic effects $[107,108]$. For these reasons, the use of HBOT has been applied as an adjunctive therapy in periodontal treatment; however, most are case reports $[109,110]$. Further controlled studies are needed to confirm the clinical potential of HBOT.

\section{Perspective and Future Directions}

Wound healing in the oral cavity is similar and different in many ways from skin wound healing. Successful periodontal wound healing after treatment can support optimal periodontal tissue regeneration. In-depth understanding of the biological factors affecting periodontal therapy has always been emphasized to optimize the clinical outcome and increase the predictability of therapy. Adjunctive use of biomaterials or devices can reinforce the healing process, and wound biomodification using therapeutic agents, such as growth factors, may amplify the regenerative potential.

Stem-cell related research has received a lot of attention for the bright future of periodontal tissue regeneration; however, several problems remain to be solved. The development of appropriate scaffolds that deliver the cells and growth factors even in the infective healing environment (due to the oral microbiome) is important for genuine tissue engineering. A well-organized strategy for the periodontal healing process is needed since the advantages of high healing potential and disadvantages of oral microbial attacks are combined. With recent ongoing advanced technologies of three-dimensional printing and next-generation sequencing for personalized medicine, ideal wound healing and tissue regeneration would be more achievable.

Author Contributions: Conceptualization, Y.-D.C. and Y.-J.S.; Methodology, Y.-D.C. and Y.-J.S.; Software, Y.-D.C. and K.-H.K.; Validation, Y.-D.C., K.-H.K., and Y.-J.S.; Investigation, Y.-D.C. and Y.-J.S.; Resources, Y.-D.C. and Y.-J.S.; Original draft preparation, Y.-D.C. and Y.-J.S.; Review and editing, Y.-D.C. and Y.-J.S.; Supervision, Y.-M.L., Y.K., and Y.-J.S. All authors have read and agreed to the published version of the manuscript.

Funding: This work was supported by the National Research Foundation of Korea (NRF) grant funded by the Korean government (MSIT) (No. NRF-2020R1A2C1007536/2020R1C1C1005830).

Data Availability Statement: Not applicable.

Conflicts of Interest: The authors report no declarations of interest.

\section{References}

1. Kinane, D.F.; Stathopoulou, P.G.; Papapanou, P.N. Periodontal diseases. Nat. Rev. Dis. Primers 2017, 3, 17038. [CrossRef]

2. Harvey, J.D. Periodontal Microbiology. Dent. Clin. N. Am. 2017, 61, 253-269. [CrossRef]

3. Socransky, S.S.; Haffajee, A.D. Dental biofilms: Difficult therapeutic targets. Periodontol 2000 2002, 28, 12-55. [CrossRef]

4. Nazir, M.; Al-Ansari, A.; Al-Khalifa, K.; Alhareky, M.; Gaffar, B.; Almas, K. Global Prevalence of Periodontal Disease and Lack of Its Surveillance. Sci. World J. 2020, 2020, 2146160. [CrossRef]

5. Dietrich, T.; Ower, P.; Tank, M.; West, N.X.; Walter, C.; Needleman, I.; Hughes, F.J.; Wadia, R.; Milward, M.R.; Hodge, P.J.; et al. Periodontal diagnosis in the context of the 2017 classification system of periodontal diseases and conditions-Implementation in clinical practice. Br. Dent. J. 2019, 226, 16-22. [CrossRef]

6. Cho, Y.D.; Kim, W.J.; Ryoo, H.M.; Kim, H.G.; Kim, K.H.; Ku, Y.; Seol, Y.J. Current advances of epigenetics in periodontology from ENCODE project: A review and future perspectives. Clin. Epigenet. 2021, 13, 92. [CrossRef]

7. Eming, S.A.; Martin, P.; Tomic-Canic, M. Wound repair and regeneration: Mechanisms, signaling, and translation. Sci. Transl. Med. 2014, 6, 265sr266. [CrossRef] [PubMed]

8. Polimeni, G.; Xiropaidis, A.V.; Wikesjo, U.M. Biology and principles of periodontal wound healing/regeneration. Periodontol 2000 2006, 41, 30-47. [CrossRef] [PubMed] 
9. Nikoloudaki, G.; Creber, K.; Hamilton, D.W. Wound healing and fibrosis: A contrasting role for periostin in skin and the oral mucosa. Am. J. Physiol. Cell Physiol. 2020, 318, C1065-C1077. [CrossRef]

10. Politis, C.; Schoenaers, J.; Jacobs, R.; Agbaje, J.O. Wound Healing Problems in the Mouth. Front. Physiol. 2016, 7, 507. [CrossRef] [PubMed]

11. Iglesias-Bartolome, R.; Uchiyama, A.; Molinolo, A.A.; Abusleme, L.; Brooks, S.R.; Callejas-Valera, J.L.; Edwards, D.; Doci, C.; Asselin-Labat, M.L.; Onaitis, M.W.; et al. Transcriptional signature primes human oral mucosa for rapid wound healing. Sci. Transl. Med. 2018, 10. [CrossRef]

12. Katsani, K.R.; Sakellari, D. Saliva proteomics updates in biomedicine. J. Biol. Res. 2019, 26, 17. [CrossRef] [PubMed]

13. Ahangar, P.; Mills, S.J.; Smith, L.E.; Gronthos, S.; Cowin, A.J. Human gingival fibroblast secretome accelerates wound healing through anti-inflammatory and pro-angiogenic mechanisms. NPJ Regen Med. 2020, 5, 24. [CrossRef]

14. Chen, L.; Arbieva, Z.H.; Guo, S.; Marucha, P.T.; Mustoe, T.A.; DiPietro, L.A. Positional differences in the wound transcriptome of skin and oral mucosa. BMC Genom. 2010, 11, 471. [CrossRef] [PubMed]

15. Leoni, G.; Neumann, P.A.; Sumagin, R.; Denning, T.L.; Nusrat, A. Wound repair: Role of immune-epithelial interactions. Mucosal Immunol. 2015, 8, 959-968. [CrossRef]

16. desJardins-Park, H.E.; Mascharak, S.; Chinta, M.S.; Wan, D.C.; Longaker, M.T. The Spectrum of Scarring in Craniofacial Wound Repair. Front. Physiol. 2019, 10, 322. [CrossRef]

17. Turabelidze, A.; Guo, S.J.; Chung, A.Y.; Chen, L.; Dai, Y.; Marucha, P.T.; DiPietro, L.A. Intrinsic Differences between Oral and Skin Keratinocytes. PLoS ONE 2014, 9. [CrossRef]

18. Glim, J.E.; Beelen, R.H.; Niessen, F.B.; Everts, V.; Ulrich, M.M. The number of immune cells is lower in healthy oral mucosa compared to skin and does not increase after scarring. Arch. Oral Biol. 2015, 60, 272-281. [CrossRef]

19. Boink, M.A.; van den Broek, L.J.; Roffel, S.; Nazmi, K.; Bolscher, J.G.; Gefen, A.; Veerman, E.C.; Gibbs, S. Different wound healing properties of dermis, adipose, and gingiva mesenchymal stromal cells. Wound Repair Regen. 2016, 24, 100-109. [CrossRef] [PubMed]

20. Szpaderska, A.M.; Zuckerman, J.D.; DiPietro, L.A. Differential injury responses in oral mucosal and cutaneous wounds. J. Dent. Res. 2003, 82, 621-626. [CrossRef]

21. Chen, L.; Gajendrareddy, P.K.; DiPietro, L.A. Differential expression of HIF-1alpha in skin and mucosal wounds. J. Dent. Res. 2012, 91, 871-876. [CrossRef]

22. Pippi, R. Post-Surgical Clinical Monitoring of Soft Tissue Wound Healing in Periodontal and Implant Surgery. Int. J. Med. Sci. 2017, 14, 721-728. [CrossRef]

23. de Sousa Gomes, P.; Daugela, P.; Poskevicius, L.; Mariano, L.; Fernandes, M.H. Molecular and Cellular Aspects of Socket Healing in the Absence and Presence of Graft Materials and Autologous Platelet Concentrates: A Focused Review. J. Oral Maxillofac. Res. 2019, 10, e2. [CrossRef]

24. Kim, J.H.; Susin, C.; Min, J.H.; Suh, H.Y.; Sang, E.J.; Ku, Y.; Wikesjo, U.M.; Koo, K.T. Extraction sockets: Erratic healing impeding factors. J. Clin. Periodontol. 2014, 41, 80-85. [CrossRef]

25. Balakrishnan, A.; Arunachalam, L.T.; Sudhakar, U. Minimally invasive surgery in periodontics-A review. IP Int. J. Periodontol. Implantol. 2019, 4, 130-137.

26. Cortellini, P.; Tonetti, M.S. Improved wound stability with a modified minimally invasive surgical technique in the regenerative treatment of isolated interdental intrabony defects. J. Clin. Periodontol. 2009, 36, 157-163. [CrossRef] [PubMed]

27. Larsson, L.; Decker, A.M.; Nibali, L.; Pilipchuk, S.P.; Berglundh, T.; Giannobile, W.V. Regenerative Medicine for Periodontal and Peri-implant Diseases. J. Dent. Res. 2016, 95, 255-266. [CrossRef] [PubMed]

28. Smitha Annie Jacob, A.D. Guided tissue regeneration: A review. J. Dent. Health Oral Disord. Ther. 2017, 6, 67-73.

29. Suchetha, A.E.T.; Darshan, B.M.; Apoorva, S.M.; Divya, B. Post-operative complications after periodontal surgery. Int. J. Appl. Dent. Sci. 2018, 4, 152-156.

30. Ria, B.; Wates, E.; Ria, S. A review of haemostasis following minor oral surgery procedures. J. Dent. Health Oral Disord. Ther. 2017, 7, 246-249. [CrossRef]

31. Jaisika Rajpal, A.A.; Ruchika, P.; Madhav Mukund, G. Preventing postoperative swelling after periodontal surgery. J. Oral. Res. Rev. 2015, 7, 31-34. [CrossRef]

32. Chappi, D.M.; Suresh, K.V.; Patil, M.R.; Desai, R.; Tauro, D.P.; Bharani, K.N.S.S.; Parkar, M.I.; Babaji, H.V. Comparison of clinical efficacy of methylprednisolone and serratiopeptidase for reduction of postoperative sequelae after lower third molar surgery. $J$. Clin. Exp. Dent. 2015, 7, e197-e202. [CrossRef] [PubMed]

33. Richardson, S.; Krishna, S.; Khandeparker, R.V. A comprehensive management protocol to treat cleft maxillary hypoplasia. J. Craniomaxillofac. Surg. 2018, 46, 356-361. [CrossRef] [PubMed]

34. Shahbazi, A.; Feigl, G.; Sculean, A.; Grimm, A.; Palkovics, D.; Molnar, B.; Windisch, P. Vascular survey of the maxillary vestibule and gingiva-clinical impact on incision and flap design in periodontal and implant surgeries. Clin. Oral Investig. 2021, 25, 539-546. [CrossRef] [PubMed]

35. Shahbazi, A.; Pilsl, U.; Molnar, B.; Feigl, G. Detection of Vascular Pathways of Oral Mucosa Influencing Soft- and Hard Tissue Surgeries by Latex Milk Injection. J. Vis. Exp. Jove 2020. [CrossRef] [PubMed] 
36. Zuhr, O.; Rebele, S.F.; Cheung, S.L.; Hurzeler, M.B.; Research Group on Oral Soft Tissue, B.; Wound, H. Surgery without papilla incision: Tunneling flap procedures in plastic periodontal and implant surgery. Periodontol 2000 2018, 77, 123-149. [CrossRef] [PubMed]

37. Kleinheinz, J.; Buchter, A.; Kruse-Losler, B.; Weingart, D.; Joos, U. Incision design in implant dentistry based on vascularization of the mucosa. Clin. Oral Implant. Res. 2005, 16, 518-523. [CrossRef]

38. Sheikh, R.; Memarzadeh, K.; Torbrand, C.; Blohme, J.; Malmsjo, M. Hypoperfusion in response to epinephrine in local anaesthetics: Investigation of dependence on epinephrine concentration, spread of hypoperfusion and time to maximal cutaneous vasoconstriction. J. Plast. Reconstr. Aesthet. Surg. 2017, 70, 322-329. [CrossRef]

39. Mikecs, B.; Vag, J.; Gerber, G.; Molnar, B.; Feigl, G.; Shahbazi, A. Revisiting the vascularity of the keratinized gingiva in the maxillary esthetic zone. BMC Oral Health 2021, 21, 160. [CrossRef]

40. Sousounis, K.; Baddour, J.A.; Tsonis, P.A. Aging and regeneration in vertebrates. Curr. Top. Dev. Biol. 2014, 108, 217-246. [CrossRef]

41. Levi, N.; Papismadov, N.; Solomonov, I.; Sagi, I.; Krizhanovsky, V. The ECM path of senescence in aging: Components and modifiers. FEBS J. 2020, 287, 2636-2646. [CrossRef]

42. Smith, P.C.; Caceres, M.; Martinez, C.; Oyarzun, A.; Martinez, J. Gingival wound healing: An essential response disturbed by aging? J. Dent. Res. 2015, 94, 395-402. [CrossRef]

43. Patel, S.; Srivastava, S.; Singh, M.R.; Singh, D. Mechanistic insight into diabetic wounds: Pathogenesis, molecular targets and treatment strategies to pace wound healing. Biomed. Pharmacother. 2019, 112, 108615. [CrossRef]

44. Catrina, S.B.; Zheng, X. Disturbed hypoxic responses as a pathogenic mechanism of diabetic foot ulcers. Diabetes Metab. Res. Rev. 2016, 32 (Suppl. 1), 179-185. [CrossRef]

45. Xu, J.; Liu, X.; Zhao, F.; Zhang, Y.; Wang, Z. HIF1alpha overexpression enhances diabetic wound closure in high glucose and low oxygen conditions by promoting adipose-derived stem cell paracrine function and survival. Stem Cell. Res. Ther. 2020, 11, 148. [CrossRef]

46. Impellizzeri, D.; Peritore, A.F.; Cordaro, M.; Gugliandolo, E.; Siracusa, R.; Crupi, R.; D’Amico, R.; Fusco, R.; Evangelista, M.; Cuzzocrea, S.; et al. The neuroprotective effects of micronized PEA (PEA-m) formulation on diabetic peripheral neuropathy in mice. FASEB J. 2019, 33, 11364-11380. [CrossRef] [PubMed]

47. Ellis, P. The impact of smoking on wound healing: The role of the nurse. Br. J. Nurs. 2018, 27, S10-S14. [CrossRef]

48. Naji, A.; Edman, K.; Holmlund, A. Influence of smoking on periodontal healing one year after active treatment. J. Clin. Periodontol. 2020, 47, 343-350. [CrossRef]

49. Ng, T.K.; Huang, L.; Cao, D.; Yip, Y.W.; Tsang, W.M.; Yam, G.H.; Pang, C.P.; Cheung, H.S. Cigarette smoking hinders human periodontal ligament-derived stem cell proliferation, migration and differentiation potentials. Sci. Rep. 2015, 5, 7828. [CrossRef] [PubMed]

50. Cho, Y.D.; Kim, P.J.; Kim, H.G.; Seol, Y.J.; Lee, Y.M.; Ku, Y.; Rhyu, I.C.; Ryoo, H.M. Transcriptomics and methylomics in chronic periodontitis with tobacco use: A pilot study. Clin. Epigenet. 2017, 9, 81. [CrossRef] [PubMed]

51. Cho, Y.D.; Kim, P.J.; Kim, H.G.; Seol, Y.J.; Lee, Y.M.; Ryoo, H.M.; Ku, Y. Transcriptome and methylome analysis of periodontitis and peri-implantitis with tobacco use. Gene 2020, 727, 144258. [CrossRef]

52. Kubota, M.; Yanagita, M.; Mori, K.; Hasegawa, S.; Yamashita, M.; Yamada, S.; Kitamura, M.; Murakami, S. The Effects of Cigarette Smoke Condensate and Nicotine on Periodontal Tissue in a Periodontitis Model Mouse. PLoS ONE 2016, 11, e0155594. [CrossRef] [PubMed]

53. Zhang, Y.; He, J.; He, B.; Huang, R.; Li, M. Effect of tobacco on periodontal disease and oral cancer. Tob. Induc. Dis. 2019, 17, 40. [CrossRef] [PubMed]

54. Deveci, B.; Ayna, B.; Tacir, I.H.; Deveci, E.; Tuncer, M.C.; Pala, A. Effects of nicotine administration in rats on MMP2 and VEGF levels in periodontal membrane. Folia Morphol. 2018, 77, 471-477. [CrossRef] [PubMed]

55. Morozumi, T.; Kubota, T.; Sato, T.; Okuda, K.; Yoshie, H. Smoking cessation increases gingival blood flow and gingival crevicular fluid. J. Clin. Periodontol. 2004, 31, 267-272. [CrossRef] [PubMed]

56. Imamura, K.; Kokubu, E.; Kita, D.; Ota, K.; Yoshikawa, K.; Ishihara, K.; Saito, A. Role of mitogen-activated protein kinase pathways in migration of gingival epithelial cells in response to stimulation by cigarette smoke condensate and infection by Porphyromonas gingivalis. J. Periodontal Res. 2016, 51, 613-621. [CrossRef] [PubMed]

57. Davies, C.S.; Ismail, A. Nicotine has deleterious effects on wound healing through increased vasoconstriction. BMJ 2016, 353, i2709. [CrossRef]

58. Villa, O.; Wohlfahrt, J.C.; Mdla, I.; Petzold, C.; Reseland, J.E.; Snead, M.L.; Lyngstadaas, S.P. Proline-Rich Peptide Mimics Effects of Enamel Matrix Derivative on Rat Oral Mucosa Incisional Wound Healing. J. Periodontol. 2015, 86, 1386-1395. [CrossRef]

59. Seshima, F.; Aoki, H.; Takeuchi, T.; Suzuki, E.; Irokawa, D.; Makino-Oi, A.; Sugito, H.; Tomita, S.; Saito, A. Periodontal regenerative therapy with enamel matrix derivative in the treatment of intrabony defects: A prospective 2-year study. BMC Res. Notes 2017, 10, 256. [CrossRef]

60. Guimaraes, G.F.; de Araujo, V.C.; Nery, J.C.; Peruzzo, D.C.; Soares, A.B. Microvessel Density Evaluation of the Effect of Enamel Matrix Derivative on Soft Tissue After Implant Placement: A Preliminary Study. Int. J. Periodontics Restor. Dent. 2015, 35, 733-738. [CrossRef] 
61. Villa, O.; Wohlfahrt, J.C.; Koldsland, O.C.; Brookes, S.J.; Lyngstadaas, S.P.; Aass, A.M.; Reseland, J.E. EMD in periodontal regenerative surgery modulates cytokine profiles: A randomised controlled clinical trial. Sci. Rep. 2016, 6, 23060. [CrossRef]

62. Takeda, K.; Mizutani, K.; Matsuura, T.; Kido, D.; Mikami, R.; Noda, M.; Buranasin, P.; Sasaki, Y.; Izumi, Y. Periodontal regenerative effect of enamel matrix derivative in diabetes. PLOS ONE 2018, 13, e0207201. [CrossRef] [PubMed]

63. Gu, L.; Shan, T.; Ma, Y.X.; Tay, F.R.; Niu, L. Novel Biomedical Applications of Crosslinked Collagen. Trends Biotechnol. 2019, 37, 464-491. [CrossRef] [PubMed]

64. Mahesh, L.; Kurtzman, G.M.; Shukla, S. Regeneration in Periodontics: Collagen-A Review of Its Properties and Applications in Dentistry. Compend. Contin. Educ. Dent. 2015, 36, 358-363.

65. Abdelaziz, M.; Shaaban, R.; Abdelhalim, S.; Sadaka, M. Effect of CollagPlug ${ }^{\circledR}$ on the healing of extraction sockets in patients under oral anticoagulant therapy. Alex. Dent. J. 2015, 40, 166-172. [CrossRef]

66. Ranganathan, M.; Balaji, M.; Krishnaraj, R.; Narayanan, V.; Thangavelu, A. Assessment of Regeneration of Bone in the Extracted Third Molar Sockets Augmented Using Xenograft (CollaPlug(TN) Zimmer) in Comparison with the Normal Healing on the Contralateral Side. J. Pharm. Bioallied Sci. 2017, 9, S180-S186. [CrossRef] [PubMed]

67. Resnik, R.R. Intraoperative Complications: Bleeding; Elsevier Inc.: Amsterdam, The Netherlands, 2018.

68. Cho, Y.D.; Seol, Y.J.; Lee, Y.M.; Heo, S.J.; Ku, Y. Immediate Implant Placement at a Periapical Lesion Site: A Case Series. J. Oral Implantol. 2018, 44, 281-286. [CrossRef]

69. Kim, Y.K.; Yun, P.Y.; Lee, H.J.; Ahn, J.Y.; Kim, S.G. Ridge preservation of the molar extraction socket using collagen sponge and xenogeneic bone grafts. Implant. Dent. 2011, 20, 267-272. [CrossRef]

70. Chang, L.C.; Cheng, Y.M. The Effect of Different Socket Types on Implant Therapy While Using Flapless Ridge Preservation. Appl. Sci. Basel 2021, 11, 970. [CrossRef]

71. Achneck, H.E.; Sileshi, B.; Jamiolkowski, R.M.; Albala, D.M.; Shapiro, M.L.; Lawson, J.H. A Comprehensive Review of Topical Hemostatic Agents Efficacy and Recommendations for Use. Ann. Surg. 2010, 251, 217-228. [CrossRef]

72. Tomizawa, Y. Clinical benefits and risk analysis of topical hemostats: A review. J. Artif. Organs 2005, 8, 137-142. [CrossRef] [PubMed]

73. Wang, J.L.; Wang, L.N.; Zhou, Z.Y.; Lai, H.J.; Xu, P.; Liao, L.; Wei, J.C. Biodegradable Polymer Membranes Applied in Guided Bone/Tissue Regeneration: A Review. Polymers 2016, 8, 115. [CrossRef]

74. Irokawa, D.; Takeuchi, T.; Noda, K.; Goto, H.; Egawa, M.; Tomita, S.; Sugito, H.; Nikaido, M.; Saito, A. Clinical outcome of periodontal regenerative therapy using collagen membrane and deproteinized bovine bone mineral: A 2.5-year follow-up study. BMC Res. Notes 2017, 10, 102. [CrossRef] [PubMed]

75. Allan, B.; Ruan, R.; Landao-Bassonga, E.; Gillman, N.; Wang, T.; Gao, J.; Ruan, Y.; Xu, Y.; Lee, C.; Goonewardene, M.; et al. Collagen Membrane for Guided Bone Regeneration in Dental and Orthopedic Applications. Tissue Eng. Part A 2021, $27,372-381$. [CrossRef]

76. Sbricoli, L.; Guazzo, R.; Annunziata, M.; Gobbato, L.; Bressan, E.; Nastri, L. Selection of Collagen Membranes for Bone Regeneration: A Literature Review. Materialsl 2020, 13, 786. [CrossRef]

77. Bubalo, M.; Lazic, Z.; Tatic, Z.; Milovic, R.; Magic, M. The use of collagen membranes in guided tissue regeneration. Vojnosanit. Pregl. 2017, 74, 767-772. [CrossRef]

78. Oh, T.J.; Meraw, S.J.; Lee, E.J.; Giannobile, W.V.; Wang, H.L. Comparative analysis of collagen membranes for the treatment of implant dehiscence defects. Clin. Oral Implant. Res. 2003, 14, 80-90. [CrossRef]

79. Silva, E.C.; Omonte, S.V.; Martins, A.G.; de Castro, H.H.; Gomes, H.E.; Zenobio, E.G.; de Oliveira, P.A.; Horta, M.C.; Souza, P.E. Hyaluronic acid on collagen membranes: An experimental study in rats. Arch. Oral Biol. 2017, 73, 214-222. [CrossRef]

80. Omar, O.; Elgali, I.; Dahlin, C.; Thomsen, P. Barrier membranes: More than the barrier effect? J. Clin. Periodontol. 2019, 46 (Suppl. 21), 103-123. [CrossRef] [PubMed]

81. Zubery, Y.; Nir, E.; Goldlust, A. Ossification of a collagen membrane cross-linked by sugar: A human case series. J. Periodontol. 2008, 79, 1101-1107. [CrossRef]

82. Almazrooa, S.A.; Noonan, V.; Woo, S.B. Resorbable collagen membranes: Histopathologic features. Oral Surg. Oral Med. Oral Pathol. Oral Radiol. 2014, 118, 236-240. [CrossRef] [PubMed]

83. Shanmugam, M.; Kumar, T.S.; Arun, K.V.; Arun, R.; Karthik, S.J. Clinical and histological evaluation of two dressing materials in the healing of palatal wounds. J. Indian Soc. Periodontol. 2010, 14, 241-244. [CrossRef] [PubMed]

84. Sharma, V.; Kumar, A.; Puri, K.; Bansal, M.; Khatri, M. Application of platelet-rich fibrin membrane and collagen dressing as palatal bandage for wound healing: A randomized clinical control trial. Indian J. Dent. Res. 2019, 30, 881-888. [CrossRef]

85. Moustafa, H.; Omar, S.; Osman, S.; Kawana, K. EFFECT OF COLLATAPE ${ }^{\circledR}$ COLLAGEN WOUND DRESSING ALONE AND COMBINED WITH INGENIOS $^{\circledR}$ SYNTHETIC BONE GRAFT ON THE SOCKET HEALING IN RABBITS. Alex. Dent. J. 2015, 40, 27-32. [CrossRef]

86. Mohan, S.P.; Jaishangar, N.; Devy, S.; Narayanan, A.; Cherian, D.; Madhavan, S.S. Platelet-Rich Plasma and Platelet-Rich Fibrin in Periodontal Regeneration: A Review. J. Pharm. Bioallied Sci. 2019, 11, S126-S130. [CrossRef]

87. Jalaluddin, M.; Mahesh, J.; Mahesh, R.; Jayanti, I.; Faizuddin, M.; Kripal, K.; Nazeer, N. Effectiveness of Platelet Rich Plasma and Bone Graft in the Treatment of Intrabony Defects: A Clinico-radiographic Study. Open Dent. J. 2018, 12, 133-154. [CrossRef]

88. Greenwell, M.A.E.a.H. Theoretical and Clinical Considerations for Autologous Blood Preparations: Platelet-Rich Plasma, Fibrin Sealants, and Plasma-Rich Growth Factors. Clin. Adv. Periodontics 2011, 1, 142-153. 
89. Jovani-Sancho, M.D.; Sheth, C.C.; Marques-Mateo, M.; Puche-Torres, M. Platelet-Rich Plasma: A Study of the Variables that May Influence Its Effect on Bone Regeneration. Clin. Implant. Dent. Relat. Res. 2016, 18, 1051-1064. [CrossRef]

90. Gentile, P.; Garcovich, S. Systematic Review-The Potential Implications of Different Platelet-Rich Plasma (PRP) Concentrations in Regenerative Medicine for Tissue Repair. Int. J. Mol. Sci. 2020, 21, 5702. [CrossRef] [PubMed]

91. Panda, S.; Purkayastha, A.; Mohanty, R.; Nayak, R.; Satpathy, A.; Das, A.C.; Kumar, M.; Mohanty, G.; Panda, S.; Fabbro, M.D. Plasma rich in growth factors (PRGF) in non-surgical periodontal therapy: A randomized clinical trial. Braz. Oral Res. 2020, 34, e034. [CrossRef]

92. Masuki, H.; Okudera, T.; Watanebe, T.; Suzuki, M.; Nishiyama, K.; Okudera, H.; Nakata, K.; Uematsu, K.; Su, C.Y.; Kawase, T. Growth factor and pro-inflammatory cytokine contents in platelet-rich plasma (PRP), plasma rich in growth factors (PRGF), advanced platelet-rich fibrin (A-PRF), and concentrated growth factors (CGF). Int. J. Implant. Dent. 2016, 2, 19. [CrossRef] [PubMed]

93. Makogonenko, E.; Tsurupa, G.; Ingham, K.; Medved, L. Interaction of fibrin(ogen) with fibronectin: Further characterization and localization of the fibronectin-binding site. Biochemistry 2002, 41, 7907-7913. [CrossRef]

94. Shaju Jacob, S.N. Fibrin Sealant: A Review of Its Applications i Periodontal Surgery. Int. J. Exp. Dent. Sci. 2015, 4, 40-46. [CrossRef]

95. Daigo, Y.; Daigo, E.; Fukuoka, H.; Fukuoka, N.; Ishikawa, M.; Takahashi, K. Wound Healing and Cell Dynamics Including Mesenchymal and Dental Pulp Stem Cells Induced by Photobiomodulation Therapy: An Example of Socket-Preserving Effects after Tooth Extraction in Rats and a Literature Review. Int. J. Mol. Sci. 2020, 21, 6850. [CrossRef] [PubMed]

96. Aoki, A.; Mizutani, K.; Schwarz, F.; Sculean, A.; Yukna, R.A.; Takasaki, A.A.; Romanos, G.E.; Taniguchi, Y.; Sasaki, K.M.; Zeredo, J.L.; et al. Periodontal and peri-implant wound healing following laser therapy. Periodontol 2000 2015, 68, 217-269. [CrossRef]

97. Dalvi, S.; Benedicenti, S.; Hanna, R. Effectiveness of Photobiomodulation as an Adjunct to Nonsurgical Periodontal Therapy in the Management of Periodontitis- A Systematic Review of in vivo Human Studies. Photochem. Photobiol. 2021, 97, 223-242. [CrossRef] [PubMed]

98. Gholami, L.; Asefi, S.; Hooshyarfard, A.; Sculean, A.; Romanos, G.E.; Aoki, A.; Fekrazad, R. Photobiomodulation in Periodontology and Implant Dentistry: Part 1. Photobiomodul. Photomed. Laser Surg. 2019, 37, 739-765. [CrossRef] [PubMed]

99. Daigo, Y.; Daigo, E.; Hasegawa, A.; Fukuoka, H.; Ishikawa, M.; Takahashi, K. Utility of High-Intensity Laser Therapy Combined with Photobiomodulation Therapy for Socket Preservation After Tooth Extraction. Photobiomodul. Photomed. Laser Surg. 2020, 38 , 75-83. [CrossRef]

100. Suter, V.G.A.; Sjolund, S.; Bornstein, M.M. Effect of laser on pain relief and wound healing of recurrent aphthous stomatitis: A systematic review. Lasers Med. Sci. 2017, 32, 953-963. [CrossRef]

101. Cayan, T.; Hasanoglu Erbasar, G.N.; Akca, G.; Kahraman, S. Comparative Evaluation of Diode Laser and Scalpel Surgery in the Treatment of Inflammatory Fibrous Hyperplasia: A Split-Mouth Study. Photobiomodul. Photomed. Laser Surg. 2019, 37, 91-98. [CrossRef]

102. Akpinar, A.; Toker, H.; Lektemur Alpan, A.; Calisir, M. Postoperative discomfort after Nd:YAG laser and conventional frenectomy: Comparison of both genders. Aust. Dent. J. 2016, 61, 71-75. [CrossRef] [PubMed]

103. Ozcelik, O.; Seydaoglu, G.; Haytac, C.M. Diode laser for harvesting de-epithelialized palatal graft in the treatment of gingival recession defects: A randomized clinical trial. J. Clin. Periodontol. 2016, 43, 63-71. [CrossRef] [PubMed]

104. Heidari, M.; Paknejad, M.; Jamali, R.; Nokhbatolfoghahaei, H.; Fekrazad, R.; Moslemi, N. Effect of laser photobiomodulation on wound healing and postoperative pain following free gingival graft: A split-mouth triple-blind randomized controlled clinical trial. J. Photochem. Photobiol. B 2017, 172, 109-114. [CrossRef] [PubMed]

105. Morimoto, C.; Takedachi, M.; Kawasaki, K.; Shimomura, J.; Murata, M.; Hirai, A.; Kawakami, K.; Sawada, K.; Iwayama, T.; Murakami, S. Hypoxia stimulates collagen hydroxylation in gingival fibroblasts and periodontal ligament cells. J. Periodontol. 2021. [CrossRef]

106. Taylor, C.T.; Doherty, G.; Fallon, P.G.; Cummins, E.P. Hypoxia-dependent regulation of inflammatory pathways in immune cells. J. Clin. Investig. 2016, 126, 3716-3724. [CrossRef]

107. Memar, M.Y.; Yekani, M.; Alizadeh, N.; Baghi, H.B. Hyperbaric oxygen therapy: Antimicrobial mechanisms and clinical application for infections. Biomed. Pharmacother. 2019, 109, 440-447. [CrossRef]

108. Dryden, M.; Cooke, J.; Salib, R.; Holding, R.; Pender, S.L.F.; Brooks, J. Hot topics in reactive oxygen therapy: Antimicrobial and immunological mechanisms, safety and clinical applications. J. Glob. Antimicrob. Resist. 2017, 8, 194-198. [CrossRef] [PubMed]

109. Wandawa, G.; Mustaqimah, D.N.; Sidik, S.; Saraswati, H.; Putri, F.A.; Auerkari, E.I. Efficacy of Hyperbaric Oxygen Therapy as an Adjunctive Therapy of Chronic Periodontitis. J. Int. Dent. Med. Res. 2017, 10, 72-75.

110. Giacon, T.A.; Giancola, F.; Paganini, M.; Tiengo, C.; Camporesi, E.M.; Bosco, G. Hyperbaric Oxygen Therapy and A-PRF Pre-Treated Implants in Severe Periodontitis: A Case Report. Int. J. Environ. Res. Public Health 2021, 18, 413. [CrossRef] 